\title{
Common milk adulteration and their detection techniques
}

\author{
Tanzina Azad and Shoeb Ahmed ${ }^{*}$ (D)
}

\begin{abstract}
Food adulteration is a global concern and developing countries are at higher risk associated with it due to lack of monitoring and policies. However, this is one of the most common phenomena that has been overlooked in many countries. Unfortunately, in contrast to common belief, milk adulterants can pose serious health hazards leading to fatal diseases. This paper presents a detailed review of common milk adulterants as well as different methods to detect the adulterants both qualitatively and quantitatively. This study is organized to be an 'adulterant based' study instead of 'techniques based' one, where qualitative detection for most of the common adulterants are enlisted and quantitative detection methods are limited to few major adulterants of milk. Apart from regular techniques, recent development in these detection techniques have also been reported. Nowadays milk is being adulterated in more sophisticated ways that demands for cutting edge research for the detection of the adulterants. This review intends to contribute towards the common knowledge base regarding possible milk adulterants and their detection techniques.
\end{abstract}

Keyword: Milk processing, Adulteration, Product safety, Dairy, ELISA

\section{Introduction}

Milk and dairy product adulteration came into global concern after breakthrough of melamine contamination in Chinese infant milk products in 2008 (Xin \& Stone, 2008). However, history of milk adulteration is very old. Swill milk scandal has been reported in 1850 which killed 8000 infants in New York alone (How we poison our children 1858). Milk is considered to be the 'ideal food' because of its abundant nutrients required by both infants and adults. It is one of the best sources for protein, fat, carbohydrate, vitamin and minerals. Unfortunately milk is being very easily adulterated throughout the world. Possible reasons behind it may include- demand and supply gap, perishable nature of milk, low purchasing capability of customer and lack of suitable detection tests (Kamthania et al. 2014). The motivation for food fraud is economic, but the impact is a real public health concern (Ellis, Brewster, Dunn, Allwood, Golovanov, \& Goodacre, 2012; Singh \& Gandhi, 2015). The situation is significantly worse in developing and underdeveloped countries due to the absence of adequate monitoring and lack of proper law

\footnotetext{
* Correspondence: shoebahmed@che.buet.ac.bd

Department of Chemical Engineering, Bangladesh University of Engineering and Technology, Dhaka 1000, Bangladesh
}

enforcement. Qualitative detection of adulterants in milk can be easily performed with chemical reactions while quantitative detections are complex and diverse. Type of quantitative detection techniques depend on the nature of adulterants in milk. For example, LC (Liquid Chromatography) and ELISA (Enzyme Linked Immunosorbent Assay) are the most common techniques used to detect foreign protein; PCR (Polymerase Chain Reaction) and PAGE (Polyacrylamide Gel Electrophoresis) are usually used to detect milk from different species as adulterants in milk of a particular species. Milk adulteration detection techniques need to be very specific and rapid, because defrauders have escaped condemnation claiming less effectiveness of the conventional detection techniques (Garcia, Sanvido, Saraiva, Zacca, Cosso, \& Eberlin, 2012).

\section{Typical adulterants in milk}

Milk powder is the second most likely food item being in the risk of adulteration after olive oil (Moore et al. 2012). Adulterants in milk mainly include addition of vegetable protein, milk from different species, addition of whey and watering which are known as economically motivated adulteration (Fischer, Schilter, Tritscher, \& Stadler, 2011; 
Singh \& Gandhi, 2015). These adulterations do not pose any severe health risk. However, some adulterants are too harmful to be overlooked. Some of the major adulterants in milk having serious adverse health effect are urea, formalin, detergents, ammonium sulphate, boric acid, caustic soda, benzoic acid, salicylic acid, hydrogen peroxide, sugars and melamine.

Common parameters that are checked to evaluate milk quality are- fat percentage, SNF (Solid-not-Fat) percentage, protein content and freezing point. Adulterants are added in milk to increase these parameters, thereby increasing the milk quality in dishonest way. For example, cane sugar, starch, sulfate salts, urea and common salts are added to increase solid-not-fat (SNF). Urea, being a natural constituent of raw milk, has a maximum limit imposed by FSSAI (Food Safety and Standards Authority of India) Act 2006 and PFA (Prevention of Food Adulteration) Rules 1955 which is to be $70 \mathrm{mg} / 100 \mathrm{ml}$. Commercial urea is added to milk to increase non-protein nitrogen content (Sharma et al. 2012). Similarly, melamine is added to increase protein content falsely (Liu et al. 2012). Ammonium sulphate is added to increase the lactometer reading by maintaining the density of diluted milk. Formalin, Salicylic acid, Benzoic acid and Hydrogen peroxide act as preservatives and increase the shelf life of the milk (Singh \& Gandhi, 2015). Since milk fat is very expensive, some manufacturers of milk and dairy products remove milk fat for additional financial gain and compensate it by adding non-milk fat such as vegetable oil. Detergents are added to emulsify and dissolve the oil in water giving a frothy solution, which is the desired characteristics of milk (Singuluri \& Sukumaran, 2014).

Unfortunately, some of the adulterants have severe health impact, sometimes in the long run. The ingestion of melamine at levels above the safety limit can induce renal failure and death in infants (Domingo, Tirelli, Nunes, Guerreiro, \& Pinto, 2014). Both peroxides and detergents in milk can cause gastro-intestinal complications, which can lead to gastritis and inflammation of the intestine. Excessive starch in the milk can cause diarrhea due to the effects of undigested starch in colon, however, accumulated starch in the body may prove very fatal for diabetic patients (Singuluri \& Sukumaran, 2014). Urea in milk overburdens the kidneys as they have to filter out more urea content from the body (Kandpal, Srivastava, \& Negi, 2012). In addition, carbonate and bicarbonates might cause disruption in hormone signaling that regulate development and reproduction (Manual of Methods of Analysis of Foods: Milk and Milk Products 2005).

\section{Qualitative detection methods}

Qualitative detection of adulterants in milk are simple color based chemical reactions. These can be performed in any Biosafety Level 1 Laboratory with availability of chemical reagents and necessary precautions. Major drawbacks of these techniques are the facts that these are valid for a limited range of concentrations and are not sufficiently precise. However, qualitative detections are advantageous because these are simple, rapid and very easy to perform. Some of the edible compounds are often used as adulterants to improve the taste of the milk. Presence of those in milk can be detected rapidly as discussed in Table 1 . However, there are some hazardous chemicals added in milk to improve the physical appearances and shelf life. Some of those are very hazardous and can lead to fatal diseases. Table 2 shows fast, yet simple hazardous chemicals detection techniques in milk. In addition, some other mixed chemicals such as soap, detergents and coloring compounds are sometimes added to the milk to improve appearance. Qualitative detection of some of those common adulterants in milk have been discussed in Table 3.

\section{Quantitative detection methods Milk adulteration with foreign proteins}

Soy, rice and almond proteins are intentionally processed into milk-like products and sold as milk supplements for consumers with lactose intolerance (Kolar et al. 1979). However, soy, wheat and almond proteins are labeled as allergens by FALCPA (Food Allergen Labeling and Consumer Protection) of 2004 (Scholl et al. 2014) while pea, rice, lupin and maize proteins are clinically recognized as allergens (Sanchez-Monge et al. 2004), (Satoh and Nakamura 2011), (Saz \& Marina, 2007). The fact that production cost of soy milk is $70 \%$ lesser than normal milk and soya bean protein is much more cheaper than milk protein, incites manufaturers to adulterate milk with soy milk (May, Fomon, \& Remigio, 1982), (Dawson, Morrill, Reddy, Minocha, \& Ramsey, 1988). Reported detection techniques for soy milk in milk are polarimetric method, isoelectric precipitation, SDS-PAGE (Sodium Dodecyl Sulfate Polyacrylamide Gel Electrophoresis), HPLC (High Performance Liquid Chromatography) and immunodiffusion method (Sharma et al. 2012). NIR (Near Infra Red) spectroscopy has been used for detecting milk powder adulteration with vegetable protein (Maraboli, Cattaneo, \& Giangiacomo, 2002). Adulteration of pasteurized or UHT (Ultra High Tempearture) milk powders with soy, pea, and wheat proteins have been reported. ELISA has been used to detect these proteins with polyclonal antibodies (Sanchez, Perez, Puyol, Calvo, \& Brett, 2002). Skimmed milk powder adulterated with soy, pea, brown rice and hydrolyzed wheat protein has been successfully isolated using UHPLC (Ultra High Performance Liquid Chromatography) (Jablonski et al. 2014). Mass spectroscopy 
Table 1 Rapid qualitative detection of different edible adulterants in milk

\begin{tabular}{|c|c|c|c|c|}
\hline Adulterant & Procedure & Observation & $\begin{array}{l}\text { Limit of detection (v/v) } \\
\text { (R. Sharma, Rajput, } \\
\text { Barui, \& N., 2012) }\end{array}$ & References \\
\hline Sugar & $\begin{array}{l}\text { Take } 5 \mathrm{~mL} \text { milk sample in a test tube. } \\
\text { Add } 1 \mathrm{~mL} \text { conc. } \mathrm{HCl} \text { and } 0.1 \mathrm{~g} \text { resorcinol } \\
\text { solution. Place the test tube in water } \\
\text { bath for } 5 \mathrm{~min} \text {. }\end{array}$ & $\begin{array}{l}\text { Appearance of red color indicates he } \\
\text { presence of added sugar. }\end{array}$ & $0.2 \%(\mathrm{w} / \mathrm{v})$ & $\begin{array}{l}\text { (Sharma et al. 2012), } \\
\text { (Kamthania et al. } \\
\text { 2014); (Arvind Singh } \\
\text { et al. 2012) }\end{array}$ \\
\hline Starch & $\begin{array}{l}\text { Take } 3 \mathrm{~mL} \text { sample in a test tube. After } \\
\text { boiling it thoroughly, cool it to room } \\
\text { temperature. Add } 1 \text { drop of } 1 \% \text { iodine } \\
\text { solution. }\end{array}$ & $\begin{array}{l}\text { Appearance of blue color indicates he } \\
\text { presence of starch. }\end{array}$ & $0.02 \%(w / v)$ & $\begin{array}{l}\text { (Sharma et al. 2012), } \\
\text { (Arvind Singh et al. } \\
\text { 2012), (Kumar et al. } \\
\text { 1998) }\end{array}$ \\
\hline \multirow[t]{2}{*}{ Glucose } & $\begin{array}{l}\text { Take } 1 \mathrm{ml} \text { of milk sample in a test tube. } \\
\text { Add } 1 \mathrm{ml} \text { of modified Barfoed's reagent. } \\
\text { Heat the mixture for exact } 3 \text { min in a } \\
\text { boiling water bath. Rapidly cool under } \\
\text { tap water. }\end{array}$ & $\begin{array}{l}\text { Immediate appearance of deep blue } \\
\text { color indicates the presence of glucose. }\end{array}$ & $0.1 \%(w / v)$ & (Sharma et al. 2011) \\
\hline & $\begin{array}{l}\text { Add one } \mathrm{ml} \text { of phosphomolybdic acid } \\
\text { reagent to the turbid solution. }\end{array}$ & & & \\
\hline Common salt & $\begin{array}{l}\text { Take } 5 \mathrm{ml} \text { of milk sample into a test tube. } \\
\text { Add } 1 \mathrm{ml} \text { of } 0.1 \mathrm{~N} \text { silver nitrate solution. } \\
\text { Mix the content thoroughly and add } \\
0.5 \mathrm{ml} \text { of } 10 \% \text { potassium chromate solution. }\end{array}$ & $\begin{array}{l}\text { Appearance of yellow color indicates } \\
\text { the presence of added salts, whereas, } \\
\text { brick red color indicates the milk free } \\
\text { from added salt. }\end{array}$ & $0.02 \%(w / v)$ & (Sharma et al. 2012) \\
\hline Buffalo milk & $\begin{array}{l}\text { Dilute the milk } 1 / 10 \text {. Put a drop of diluted } \\
\text { milk on the centre of a glass slide. Now } \\
\text { place a drops of Hansa test serum } \\
\text { (duly preserved) on the drop of milk and } \\
\text { mix together with a glass rod or clean } \\
\text { tooth pick. }\end{array}$ & $\begin{array}{l}\text { Curdy particles develop within half a } \\
\text { minute in milk containing buffalo milk. }\end{array}$ & & $\begin{array}{l}\text { (Kamthania et al. } \\
\text { 2014); (Arvind Singh } \\
\text { et al. 2012) }\end{array}$ \\
\hline
\end{tabular}

based techniques to identify milk protein structures have been reported in (Siciliano, Rega, Amoresano, \& Pucci, 2000). Selectivity of tetraborate-EDTA buffer for extracting plant proteins from milk has been used to develop a rapid turbidimetric detection system to detect insoluble plant protein (Scholl et al. 2014).

\section{Milk adulteration with milk from different sources}

Though mixing milk from random sources and different animal species is the easiest means to adulterate milk, its quantitative detection is much more complex due to genetic and nongenetic polymorphism (Recio, Perez-Rodrlguez, Ramos, \& Amigo, 1997). Determination of geographical origin of milk has been possible using ICP-OES (Inductively Coupled Plasma Emission Spectroscopy). Along with isotope ratio mass spectrometry (IRMS), this method determines the mineral contents (inorganic metals and nonmetals) of the food and identifies geographical differences utilizing chemometric techniques based on multivariate statistical methods (Bakircioglu, Kurtulus, \& Ucar, 2011; Brescia, Caldarola, Buccolieri, Dell'Atti, \& Sacco, 2003). Cow milk adulteration in caprine milk has been quantified by HPLC/ESIMS (High Performance Liquid Chromatography/Electrospray Ionization- Mass Spectroscopy) (Chen et al. 2004). This method identifies molecular masses to differentiate between proteins in the milk of cow and goat. Detection of addition of cow milk to goat and ewe milk has been described by (Abrantes et al. 2014; Romero, PerezAndújar, Olmedo, \& Jiménez, 1996; Song, Xue, \& Han, 2011). Since, PDO (Protected Denomination of Origin) cheeses are products of high commercial value confined according to legislative and proper labelling rules, different analytical techniques have been developed to evaluate the authenticity. Quantification and adulteration measurement of bovine, ovine and caprine milk mixtures in commercial PDO cheeses have been quantified by using RP-HPLC (Reverse Phase High Performance Liquid Chromatography) (Ferreira \& Cacote, 2003; Guerreiro, Barros, Fernandes, Pires, \& Bardsley, 2013), high resolution melting (HRM) based method utilizing specific mitochondrial primers (Ganopoulos, Sakaridis, Argiriou, Madesis, \& Tsaftaris, 2013) and solid-phase microextraction-mass spectrometry method (SPME-MS) based on volatile profile (Majcher, Kaczmarek, Klensporf-Pawlik, Pikul, \& Jeleń, 2015). Indirect competitive ELISA has been used to detect cow milk adulteration in goat, sheep and buffalo milk (Hurley et al. 2004). Adulteration of caprine milk with cow milk has also been detected using PCR (Bania et al. 2001). In addition, PCR has been used to detect cow milk in ewe milk (López-Calleja et al. 2004), goat cheese (Maudet \& Taberlet, 2001) and in buffalo mozzarella cheese (Bottero, Civera, Anastasio, Turi, \& Rosati, 2002). An electronic tongue that is capable to recognize 5 basic taste standards has been used to detect caprine milk adulteration in bovine milk (Dias, Peres, Veloso, Reis, Vilas-Boas, \& Machado, 
Table 2 Rapid qualitative detection of different hazardous chemicals in milk

\begin{tabular}{|c|c|c|c|c|}
\hline Adulterant & Procedure & Observation & $\begin{array}{l}\text { Limit of detection } \\
(\mathrm{v} / \mathrm{v})(\text { Sharma } \\
\text { et al. 2012) }\end{array}$ & References \\
\hline \multirow[t]{2}{*}{$\begin{array}{l}\text { Hydrogen } \\
\text { peroxide }\end{array}$} & $\begin{array}{l}\text { A. Add to } 5 \mathrm{~mL} \text { of suspected milk sample } \\
\text { in attest tube, an equal volume of } \\
\text { raw milk and } 5 \text { drops of } 2 \% \text { solution } \\
\text { of paraphenylenediamine. }\end{array}$ & $\begin{array}{l}\text { Appearance of blue color indicates } \\
\text { the presence of hydrogen peroxide } \\
\text { as adulterant. }\end{array}$ & $0.025 \%$ & $\begin{array}{l}\text { (Anvind Singh et al. 2012) } \\
\text { (Kamthania et al. 2014); } \\
\text { (Sharma et al. 2012) }\end{array}$ \\
\hline & $\begin{array}{l}\text { B. Take } 1 \mathrm{~mL} \text { milk sample in a test tube and } \\
\text { add } 1 \mathrm{~mL} \text { of potassium iodide-starch } \\
\text { reagent solution and mix well. }\end{array}$ & $\begin{array}{l}\text { Appearance of blue color indicates } \\
\text { the presence of hydrogen peroxide } \\
\text { as adulterant. }\end{array}$ & $0.004 \%$ & (Sharma et al. 2012) \\
\hline \multirow[t]{2}{*}{ Formalin } & $\begin{array}{l}\text { A. Take } 10 \mathrm{~mL} \text { milk sample in attest tube. } \\
\text { Add } 5 \mathrm{~mL} \text { conc. sulfuric acid with a little } \\
\text { amount of ferric chloride without shaking. }\end{array}$ & $\begin{array}{l}\text { Appearance of violet or blue color } \\
\text { at the junction of two liquid layers } \\
\text { indicates the presence of formalin. }\end{array}$ & & $\begin{array}{l}\text { (Arvind Singh et al. } \\
\text { 2012); (Kamthania et al. } \\
\text { 2014) }\end{array}$ \\
\hline & B. Take about $5 \mathrm{ml}$ of milk in a test tube. & Appearance of brownish pink color & $0.1 \%$ & (Sharma et al. 2012) \\
\hline
\end{tabular}

Take $1 \mathrm{ml}$ of $10 \%$ ferric chloride solution indicates the presence of formalin.

in a $500 \mathrm{ml}$ volumetric flask and make up the volume using concentrated hydrochloric acid. Add $5 \mathrm{~mL}$ from this solution to the sample in test tube. Keep the tube in boiling water bath for about 3-4 min.

C. Take $1 \mathrm{~mL}$ of sample milk in a test tube. Take saturated solution of 1 ,

8- dihydroxynaphthalene-3, 6- disulphonic acid in about $72 \%$ sulfuric acid to make chromotropic acid solution. Add $1 \mathrm{~mL}$ of chromotropic acid solution to the sample in test tube.

Ammonium A. Take $2 \mathrm{ml}$. milk in a test tube and add sulfate $\quad 0.5 \mathrm{ml} \mathrm{NaOH}(2 \%) 0.5 \mathrm{ml}$ sodium hypochlorite (2\%) and $0.5 \mathrm{ml}$ phenol (5\%) Heat in boiling water bath for $20 \mathrm{sec}$

B. Take $10 \mathrm{ml}$ of milk in a $50 \mathrm{ml}$ stoppered test tube. Add $10 \mathrm{ml}$ of TCA solution. Filter the coagulated milk through Whatman filter paper Grade 42. Take $5 \mathrm{ml}$ of clear filtrate. Add few drops of barium chloride solution.

Urea $\quad$ A. Take $5 \mathrm{~mL}$ milk sample in a test tube. Add equal volume of $24 \%$ TCA to precipitate fat and proteins of milk. Take $1 \mathrm{~mL}$ filtrate and add $0.5 \mathrm{~mL} 2 \%$ sodium hypochlorite, $0.5 \mathrm{~mL} 2 \%$ sodium hydroxide and add $0.5 \mathrm{~mL}$ 5\% phenol solution, then mix.

B. Take $5 \mathrm{ml}$ milk in a test tube, add $0.2 \mathrm{ml}$ urease $(20 \mathrm{mg} / \mathrm{ml})$ Shake well at room temperature and then add $0.1 \mathrm{ml}$ Bromothymol Blue (BTB) solution (0.5\%)

C. Take $5 \mathrm{~mL}$ milk sample in a test tube. Add $5 \mathrm{~mL}$ p-Dimethyl Amino Benzaldehyde reagent.

Nitrate $\quad$ Take $10 \mathrm{ml}$ sample milk in a beaker. Add $10 \mathrm{ml}$ mercuric chloride solution to it. After mixing, filter through what man No 42 filter paper. Take $1 \mathrm{ml}$ filtrate in a test tube and add $4 \mathrm{ml}$ of diphenyl amine sulphate or diphenylbenzidine reagent.
Appearance of brownish pink color indicates the presence of formalin.

A bluish colour forms immediately, which turns deep blue afterward. Pure milk shows salmon pink colour which gradually changes to bluish after 2 hours.

Formation of milky-white precipitates indicates the presence of added sulfates like ammonium sulfate, sodium sulfate, zinc sulfate and magnesium sulfate etc to milk

A characteristic blue or bluish green colour develops in presence of added urea whereas pure milk remains colourless.

Appearance of blue colour after 10-15 min. indicates the presence of urea in milk. Normal milk shows faint blue colour due to natural urea present in milk.

Appearance of distinct yellow color indicates presence of added urea whereas formation of slight yellow color indicates natural urea in milk.

Appearance of blue colour indicates the presence of nitrates. Pure milk sample will not develop any color.
(Kumar et al. 2002)

(Meisel 1995)

(Sharma et al. 1993); (Arvind Singh et al. 2012),

$0.2 \%(\mathrm{w} / \mathrm{v})$

(Sharma et al. 1993); (Arvind Singh et al. 2012); (Bector et al. 1998); (Kavita, 2000)

(Sharma et al. 2011) 
Table 2 Rapid qualitative detection of different hazardous chemicals in milk (Continued)

\begin{tabular}{|c|c|c|c|}
\hline $\begin{array}{l}\text { Benzoic and } \\
\text { salicylic acid }\end{array}$ & $\begin{array}{l}\text { Take } 5 \mathrm{~mL} \text { milk sample in a test tube. Upon } \\
\text { acidification with sulfuric acid, } 0.5 \% \text { ferric } \\
\text { chloride solution is added to it drop by drop. } \\
\text { Mix it. Five } \mathrm{ml} \text { of milk is taken in a test tube } \\
\text { and acidified with concentrated sulphuric acid. } \\
0.5 \% \text { ferric chloride solution is added drop by } \\
\text { drop and mixed well. Development of buff } \\
\text { colour indicates presence of benzoic acid and } \\
\text { violet colour indicates salicylic acid. }\end{array}$ & $\begin{array}{l}\text { Appearance of buff color indicates the } \\
\text { presence of benzoic acid whereas } \\
\text { that of violet color indicates salicylic acid. }\end{array}$ & (Arvind Singh et al. 2012) \\
\hline $\begin{array}{l}\text { Borax and } \\
\text { boric acid }\end{array}$ & $\begin{array}{l}\text { Take } 5 \mathrm{~mL} \text { milk sample in a test tube. Add } \\
1 \mathrm{~mL} \text { conc. } \mathrm{HCl} \text { to it. A turmeric paper is } \\
\text { dipped and it is dried in a watch glass } \\
\text { at } 100^{\circ} \mathrm{C} \text {. }\end{array}$ & $\begin{array}{l}\text { If the turmeric paper turns red, it } \\
\text { indicates the presence of borax or } \\
\text { boric acid. }\end{array}$ & (Arvind Singh et al. 2012) \\
\hline
\end{tabular}

2009). This is an alternative method to classical analytical methods. PAGE has been employed to analyze the individual protein group (Strange, Malin, Van Hekken, \& Basch, 1992). Addition of bovine milk in ewe yoghurt (Kaminarides \& Koukiassa, 2002) and goat milk (Tamime, Barclay, Law, Leaver, Anifantakis, \& O'connor, 1999) have been quantified with PAGE too. Using IES (Isoelectric Focusing) instead of PAGE is more advantageous in these applications (Borková \& Snášelová, 2005). Immunochemical and DNA based methods have been combined as PCR- LCR- EIA (Polymerase Chain Reaction - Ligase Chain Reaction- Enzyme Immunoassay) to detect one specific nucleotide present in bovine milk as adulterant in ewe, goat and buffalo milk (Klotz \& Einspanier, 2001). Hydrophobic interactive chromatography is used for separation and determination of different caseins in bovine, ewe and goat milk (Bramanti et al. 2003).

\section{Milk adulteration with melamine}

Since melamine is neither a permitted additive nor a food ingredient, its limit had not been set in food legislation until the melamine contamination reported in China in 2008. Both the European Commission and the United States Food and Drug Administration (USFDA) have applied a maximum acceptable limit of $2.5 \mathrm{mg} / \mathrm{kg}$ for melamine in imported foods, and $1 \mathrm{mg} / \mathrm{kg}$ in infant formula (Lawley, 2013). This was later adopted by United Nation's food standard body, Codex Alimentarius Commission through a new rulings in 2010 (Domingo, Tirelli, Nunes, Guerreiro, \& Pinto, 2014; FAO, 2010; B. Liu, Lin, \& Li, 2010). Melamine is not only added to milk powder as adulterant, but also in many other foods like wheat gluten, chicken feed, and processed foods (Ingelfinger, 2008; Lin et al. 2008). Though it is not carcinogenic, it causes renal failure and infant death in

Table 3 Rapid qualitative detection of different mixed adulterants in milk

\begin{tabular}{|c|c|c|c|c|}
\hline Adulterant & Procedure & Observation & $\begin{array}{l}\text { Limit of detection } \\
(v / v) \text { (Sharma } \\
\text { et al. 2012) }\end{array}$ & References \\
\hline \multirow[t]{2}{*}{ Detergent } & $\begin{array}{l}\text { A. Take } 5 \mathrm{ml} \text { in a test tube and add } 0.1 \mathrm{ml} \\
\text { 0.5\% Bromocresol Purple (BCP) solution. }\end{array}$ & $\begin{array}{l}\text { Appearance of violet colour indicates } \\
\text { the presence of detergent. } \\
\text { Unadulterated milk shows faint } \\
\text { violet color. }\end{array}$ & & $\begin{array}{l}\text { (Singhal, 1980); (Arvind } \\
\text { Singh et al. 2012) }\end{array}$ \\
\hline & $\begin{array}{l}\text { B. Take } 5 \mathrm{~mL} \text { of milk sample into a } 15 \mathrm{~mL} \\
\text { test tube. Add } 1 \mathrm{ml} \text { of Methylene blue } \\
\text { dye solution and } 2 \mathrm{ml} \text { chloroform. Vortex } \\
\text { the contents for about } 15 \mathrm{sec} \text { and } \\
\text { centrifuge at about } 1100 \mathrm{rpm} \text { for } 3 \mathrm{~min} \text {. }\end{array}$ & $\begin{array}{l}\text { Relatively, more intense blue color in } \\
\text { lower layer indicates presence of } \\
\text { detergent in milk. Relatively more } \\
\text { intense blue color in upper layer } \\
\text { indicates absence of detergent in milk. }\end{array}$ & $0.0125 \%$ & (Rajput, Sharma, \& Kaur) \\
\hline $\begin{array}{l}\text { Pulverized } \\
\text { soap }\end{array}$ & $\begin{array}{l}\text { Take } 10 \mathrm{ml} \text { milk sample in a test tube. Add } \\
\text { equal quantity of hot water to it, then add } \\
1-2 \text { drops of phenolphthalein indicator. }\end{array}$ & $\begin{array}{l}\text { Appearance of pink color indicates } \\
\text { presence of soap. }\end{array}$ & & $\begin{array}{l}\text { (Arvind Singh et al. 2012); } \\
\text { (Kamthania et al. 2014); } \\
\text { (Ghodekar 1974) }\end{array}$ \\
\hline \multirow[t]{3}{*}{$\begin{array}{l}\text { Coloring } \\
\text { matter }\end{array}$} & $\begin{array}{l}\text { A. Take } 10 \mathrm{~mL} \text { milk sample in attest tube. } \\
\text { Add } 10 \mathrm{ml} \text { diethyl ether. After shaking, } \\
\text { allow it to stand. }\end{array}$ & $\begin{array}{l}\text { Appearance of yellow color in ethereal } \\
\text { layer indicates the presence of added color. }\end{array}$ & & (Batis et al. 1981) \\
\hline & $\begin{array}{l}\text { B. Make the milk sample alkaline with } \\
\text { sodium bicarbonate. Dip a strip of filter } \\
\text { paper for } 2 \text { hours. }\end{array}$ & $\begin{array}{l}\text { Appearance of red color on filter paper } \\
\text { indicates the presence of annatto. } \\
\text { Treatment of this paper with stannous } \\
\text { chloride gives pink color. }\end{array}$ & & $\begin{array}{l}\text { (Lechner and Klostermeyer } \\
\text { 1981) }\end{array}$ \\
\hline & $\begin{array}{l}\text { C. Add a few drops of hydrochloric acid to } \\
\text { milk sample. }\end{array}$ & $\begin{array}{l}\text { Appearance of pink color indicates } \\
\text { azo dyes. }\end{array}$ & & (DE Souza et al. 2000) \\
\hline
\end{tabular}


extreme cases (Cheng et al. 2010) Quantitatively melamine detection has been possible using SERS (Surface Enhanced Raman Spectroscopy) (Zhang, Zou, Qi, Liu, Zhu, \& Zhao, 2010). A portable sensor based on SERS has been also developed to detect melamine instantly (Kim, Barcelo, Williams, \& Li, 2012). SB-ATR FTIR (Single Bounce Attenuated Total Reflectance - Fourier transform infrared spectroscopy) has been used to quantify melamine in both liquid and powder milk (Jawaid et al. 2013). Different types of mass spectroscopy have been employed to detect melamine in milk products including LC-MS/MS, APCIMS (Atmospheric Pressure Chemical Ionization-Mass Spectroscopy) and EESI-MS (Extractive Electrospray Ionization Mass Spectrometry) (Yang et al. 2009; Zhu et al. 2009). LC-MS/MS has been used frequently to detect melamine in milk and variety of infant formulas (Chang \& Arora 2008; Guelph 2008; Michael Smoker, 2008; Sherri et al. 2008). HPLC is another choice of technique to quantify melamine in milk and dairy products (Gopalakrishnan Venkatasami, 2010; Ruicheng Wei et al. 2009). Using Raman band at $676 \mathrm{~cm}^{-1}$, melamine in dried milk powder has been immediately detected without extracting melamine from milk (Okazaki et al. 2009). A portable screening system based on Laser Raman spectroscopy has been developed to quantify melamine (Cheng et al. 2010). Gold nanoparticles have been developed whose surface is grafted with melamine and cyanuric acid derivative. Upon binding to melamine these nanoparticles change color from red to blue instantly which can be used as an on-site melamine detection method (Ai, Liu, \& Lu, 2009). Use of oxidized polycrystalline gold electrode has been reported to detect melamine, along with conventional approach like GC-MS (Tsai, Thiagarajan, \& Chen, 2010; Veyrand et al. 2009). Recent developments in melamine detection have been discussed in (Liu et al. 2012).

\section{Milk adulteration with urea}

Urea, being a natural constituent of milk, constitutes the major portion of non-protein nitrogen in milk. According to FSSAI act 2006 and PFA rules 1955, maximum allowable limit for urea in milk is $70 \mathrm{mg} / 100 \mathrm{~mL}$ (Sharma et al. 2012). Milk can be adulterated with urea in two ways - by intentional addition of urea and by addition of unspecified synthetic milk to natural milk. Near infrared Raman spectroscopy has been used to quantify the presence of urea without requiring any preprocessing (Khan et al. 2014). LC has been used to quantify urea as adulterant in milk (Dai et al. 2013). A method based on GC/IDMS (Gas Chromatography/Isotope Dilution Mass Spectrometry) has been used to quantify urea present in milk (Xinhua Dai et al. 2010). HPLC has been reported to detect the presence of natural urea in milk with a suggestion to convert the urea into a derivative containing a chromaphore before HPLC analysis (Czauderna \&
Kowalczyk, 2009). A combination of kjeldahl and spectrophotometric method has been suggested to detect milk adulteration by melamine, urea and ammonium sulphate (Virginia de Lourdes et al. 2013). Six different detection methods of urea have been discussed with their advantages and disadvantages by (Banupriya et al. 2014). Infrared ray absorbs ammonia at a characteristic wavelength of $1530 \mathrm{~nm}$ - this principle is used in a PCB-integrated optical waveguide sensor that enables the detection of multiple analytes including ammonia (Bamiedakis et al. 2013). A gas sensor based on a FET (Field Effect Transistor) with a graphene channel and IL (Ionic Liquid) gate has been developed that can detect at least $30 \mathrm{ppm}$ of ammonia and $4000 \mathrm{ppm}$ of carbon dioxide at gate voltage below $1 \mathrm{~V}$, which can be used to detect urea in milk (Inaba et al. 2013). An enzyme based pizo-electric sensor has been developed to detect urea in milk where a linear behavior was found between equivalent electrical signal and amount of ammonia gas present (Renny, Daniel, Krastanov, Zachariah, \& Elizabeth, 2005). EISCAP (Electrolyte Insulator Semiconductor Capacitor), a potentiometric biosensor based on enzymatic reaction has been developed to detect urea (Indranil Basu et al. 2004). Some other biosensors based on various principles like manometry, enzyme, potentiometry have already been developed to detect urea in milk (Renny et al. 2014; Mishra et al. 2010; Jenkins and Delwiche 2002; Trivedi et al. 2009).

\section{Milk adulteration with other compounds}

NIR spectroscopy (1100-2500 $\mathrm{nm}$ ) has been used to quantify water and whey in cow milk (Kasemsumran et al. 2007). In a comparative experimental study between NIR and MIR (Medium Infra Red) spectroscopy, Santos et al. (2013a) developed a portable spectrometer and commented that MIR performed better than NIR to detect the adulterants such as tap water, whey, hydrogen peroxide, synthetic urea and urine. Like urea, synthetic urine is also used in milk to increase the nitrogen content. In a case study performed in Brazil, urine was detected in all samples of UHT milk by following a chemometric approach (Souza et al. 2011). Presence of synthetic urine up to the concentration of $0.78 \mathrm{mg} / \mathrm{L}$ of milk can be identified by a method using infrared microspectroscopy and chemometric analysis (Santos et al. 2013b). Similar approach has been reported to be used in developing a portable and hand-held infrared spectrometer for milk analysis (Santos et al. 2013c). Presence of urine has also been reported by observing change in the concentration of sodium and calcium in samples undergoing flame atomic absorption spectroscopy (Santos et al. 2012). MALDI-QTOF MS (Matrix-assisted Laser Desorption/ Ionization Time of Flight Mass Spectroscopy) has been used to quantify vegetable oil in milk (Garcia, Sanvido, 
Saraiva, Zacca, Cosso, \& Eberlin, 2012). It has also been possible to detect multiple adulterants including ammonium sulfate, dicyandiamide, melamine and urea in milk powder using Raman chemical imaging (Qin et al. 2013). Milk fat adulteration is also a very common concern, however, several techniques have been developed to detect the adulteration based on Butyro Refractometer (Arora et al. 1996), fluorescence spectroscopy (Ntakatsane, Liu, \& Zhou, 2013), derivative spectroscopy (Jirankalgikar \& De, 2014) and Raman spectroscopy (Uysal, Boyaci, Genis, \& Tamer, 2013).

\section{Conclusion}

Although financial gain is considered to be one of the major reasons for milk adulteration, inadequate supply for the increasing population all over the world has paved the ground for this as well. This problem is more acute in the developing and under developed countries due to lack of adequate monitoring and law enforcement. Existing common detection techniques are not always convenient and accessible in these countries making it difficult to address the diverse ways of fraudulent adulteration in milk. This calls for combined efforts from scientific communities and the regulatory authorities through the development, implementation and dissemination of better techniques for the detection of milk adulteration. In addition, awareness and access to information can play vital role in these regions to overcome this issue. Some of these easy detection methods at the consumer level and state of the art techniques at the authority level can bring this problem to an end for the victims, including millions of children in the developing countries.

\begin{abstract}
Abbreviations
EISCAP: Electrolyte insulator semiconductor capacitor; ELISA: Enzyme linked immunosorbent assay; FALCPA: Food allergen labeling and consumer protection; FSSAI: Food Safety and Standards Authority of India; FTIR: Fourier transform infrared spectroscopy; HPLC ESI-MS: High Performance liquid chromatography electrospray ionization mass spectroscopy; HPLC: High performance liquid chromatography; ICP-OES: Inductively coupled plasma emission spectroscopy; IES: Isoelectric focusing; MALDI-QTOF MS: Matrixassisted laser desorption/ionization time of flight mass spectroscopy; MIR: Medium infra-red; MS: Mass spectroscopy; NIR: Near infra-red; PAGE: Polyacrylamide gel electrophoresis; PCR: Polymerase chain reaction; PCR-LCR-EIA: Polymerase chain reaction - ligase chain reaction- enzyme immunoassay; PDO: Protected denomination of origin; PFA: Prevention of food adulteration; RP-HPLC: Reverse phase high performance liquid chromatography; SB ATR: Single bounce attenuated total reflectance; SDS-PAGE: Sodium dodecyl sulfate polyacrylamide gel electrophoresis; SERS: Surface enhanced raman spectroscopy; SNF: Solid not fat; UHPLC: Ultra high performance liquid chromatography; UHT: Ultra high temperature
\end{abstract}

\section{Authors' contributions}

SA contributed to conception and design of the study, TA performed all the literature study, both authors contributed in manuscript preparation. Both authors read and approved the final manuscript

\section{Competing interests}

The authors declared that they have no competing interests.
Received: 4 October 2016 Accepted: 18 November 2016

Published online: 05 December 2016

\section{References}

Abrantes MR, De Oliveira ARM, De Oliveira Cabral Rocha M, De Souza GO, Telles EO, Sakamoto SM, Da Silva JBA. Detection of bovine milk contaminants in adulterated milk and curd goat cheese. Acta Sci Vet. 2014;42:1.

Ai K, Liu Y, Lu L. Hydrogen-bonding recognition-induced color change of gold nanoparticles for visual detection of melamine in raw milk and infant formula. J Am Chem Soc. 2009;131(27):9496-7.

Arora KL, Lal D, Seth R, Ram J. Platform test for detection of refined mustard oil adulteration in milk. Indian J Dairy Sci. 1996;49(10):721-3.

Arvind Singh GC, Aggarwal A, Kumar P. Adulteration Detection in Milk. Res News For U (RNFU). 2012;5:52-5

Bakircioglu D, Kurtulus YB, Ucar G. Determination of some traces metal levels in cheese samples packaged in plastic and tin containers by ICP-OES after dry, wet and microwave digestion. Food Chem Toxicol. 2011:49(1):202-7.

Bamiedakis N, Hutter T, Penty RV, White IH, Elliott SR. Pcb- integrated optical wave guide sensors: an ammonia gas sensor. J Lightwave Technol. 2013; 31(10):1628-35.

Bania J, Ugorski M, Polanowski A, Adamczyk E. Application of polymerase chain reaction for detection of goats' milk adulteration by milk of cow. J Dairy Res. 2001:68:333-6.

Banupriya PCRS, Supriya TV, Varshitha V. Comparison of different methods used for detection of urea in milk by quantification of ammonia. Int J Adv Res Elect, Electron Instrum Eng. 2014;3(3):7858-63.

Batis VK, Garg SK, Chander H, Ranganathan B. Indian Dairyman. 1981;33:435.

Bector BS, Ram M, Singhal OP. Rapid platform test for the detection/ determination of added urea in milk. Indian Dairyman. 1998;50(4):59-62.

Borková M, Snášelová J. Possibilities of different animal milk detection in milk and dairy products - a review. Czech J Food Sci. 2005;23(2):41-50.

Bottero MT, Civera T, Anastasio A, Turi RM, Rosati S. Identification of cow's milk in buffalo cheese by duplex polymerase chain reaction. J Food Prot. 2002;65:362-6

Bramanti E, Sortino C, Onor M, Beni F, Raspi G. Separation and determination of denatured as 1-, as2-, $\beta$ - and $\mathrm{k}$-caseins by hydrophobic interaction chromatography in cows', ewes' and goats' milk, milk mixtures and cheeses. J Chromatogr A. 2003:994:59-74.

Brescia M, Caldarola V, Buccolieri G, Dell'Atti A, Sacco A. Chemometric determination of the geographical origin of cow milk using icp-oes data and isotopic ratios: a preliminary study. Ital J Food Sci. 2003;15:3.

Chang E, Arora I. Simultaneous, Fast Analysis of Melamine, Cyanuric Acid, and Related Compounds in Milk and Infant Formula by LC/MS/MS. 2008. (pp. 1 4): http://www.ingenieria-analitica.com/downloads/d/file/id/2737/product/ 110/simultaneous_fast_analysis_of_melamine_cyanuric_acid_and_related_ compounds_in_milk_and_infant_formula_by_lc_ms_ms.pdf.

Chen RK, Chang LW, Chung YY, Lee MH, Ling YC. Quantification of cow milk adulteration in goat milk using high-performance liquid chromatography with electrospray ionization mass spectrometry. Rapid Commun Mass Spectrom. 2004;18:1167-71.

Cheng Y, Dong Y, Wu J, Yang X, Bai H, Zheng H. Screening melamine adulterant in milk powder with laser Raman spectrometry. J Food Composit Anal. 2010;23(2):199-202.

Czauderna M, Kowalczyk J. Easy and accurate determination of urea in milk, blood plasma, urine and selected diets of mammals by high-performance liquid chromatography with photodiode array detection preceded by precolumn derivatization. Chemia Analityczna. 2009:54:919-37.

Dai X, Zhao Y, Li M, Fang X, Li X, Li H, Xu B. Determination of urea in milk by liquid chromatography-isotope dilution mass spectrometry. Analytical Letters. 2013:45:1557-65.

Dawson DP, Morrill JL, Reddy PG, Minocha HC, Ramsey HA. Soy protein concentrate and heated soy flours as protein sources in milk replacer for preruminant calves. J Dairy Sci. 1988;71:1301-9.

DE Souza EMT, Arruda SF, Brandao PO, Siqueira EM, Almeida D. Electrophoretic analysis to detect and quantify additional whey in milk and dairy beverages. Ciênc Tecnol Aliment. 2000;20(3):314-7.

Dias LA, Peres AM, Veloso ACA, Reis FS, Vilas-Boas M, Machado AASC. An electronic tonque taste evaluation: Identification of goat milk adulteration with bovine milk. Sens Actuators B: Chem. 2009;136(1):209-17. 
Domingo E, Tirelli AA, Nunes CA, Guerreiro MC, Pinto SM. Melamine detection in milk using vibrational spectroscopy and chemometrics analysis: A review. Food Res Int. 2014;60:131-9.

Ellis DI, Brewster VL, Dunn WB, Allwood JW, Golovanov AP, Goodacre R. Fingerprinting food: current technologies for the detection of food adulteration and contamination. Chem Soc Rev. 2012:41(17):5706-27.

FAO. In: Alimentarius C, editor. International experts limit melamine levels in food, vol. 2016. Geneva: Food and Agriculture Organization; 2010.

Ferreira I, Cacote H. Detection and quantification of bovine, ovine and caprine milk percentages in protected denomination of origin cheeses by reversed phase high-performance liquid chromatography of beta- lactoglobulins. J Chromatogr A. 2003;1015:111-8.

Fischer W, Schilter B, Tritscher A, Stadler R. Contaminants of milk and dairy products: contamination resulting from farm and dairy practices. Encyclopedia of Dairy Sciences. 2011;2:887-97.

Ganopoulos I, Sakaridis I, Argiriou A, Madesis P, Tsaftaris A. A novel closed-tube method based on high resolution melting (HRM) analysis for authenticity testing and quantitative detection in Greek PDO Feta cheese. Food Chem. 2013;141(2):835-40

Garcia JS, Sanvido GB, Saraiva SA, Zacca JJ, Cosso RG, Eberlin MN. Bovine milk powder adulteration with vegetable oils or fats revealed by MALDI-QTOF MS. Food Chem. 2012;131(2012):722-6. 131 722-726.

Ghodekar DR, Dudani AJ, Ranganathan B. Microbiological quality of Indian milk products. J Milk Food Technol. 1974;37(3):119-122.

Guelph U. Determination of residues of melamine and cyanuric acid in animal food by LCMS/MS. Guelph: University of Guelph, Laboratory Services Division; 2008. p. 1-31.

Guerreiro JS, Barros M, Fernandes P, Pires P, Bardsley R. Principal component analysis of proteolytic profiles as markers of authenticity of PDO cheeses. Food Chem. 2013;136(3-4):1526-32.

How we poison our children. 1858. New York Times. New York

Hurley IP, Coleman RC, Ireland HE, Williams JHH. Measurement of bovine IgG by indirect competitive ELISA as a means of detecting milk adulteration. J Dairy Sci. 2004;87:543-9.

Inaba A, Yoo G, Takei Y, Matsumoto K, Shimoyama I. A graphene fet gas sensor gated by ionic liquid digital object identifier: 10.1109/memsys.2013.6474408 publication year: 2013, page(s): 969-972. In: IEEE 26th International Conference on Micro Electro Mechanical Systems (MEMS). Taipei: IEEE; 2013. p. 969-72.

Indranil Basu RVS, Mathew A, Chadha A, Bhattacharya E. Potentiometric biosensors based on silicon and porous silicon. NSTI-Nanotech. 2004;1:224-7.

Ingelfinger JR. Melamine and the global implications of food contamination. New England J Med. 2008;359(26):2745-8.

Jablonski JE, Moore JC, Harnly JM. Nontargeted detection of adulteration of skim milk powder with foreign proteins using UHPLC - UV. J Agric Food Chem. 2014;62:5198-206.

Jawaid S, Talpur FN, Sherazi ST, Nizamani SM, Khaskheli AA. Rapid detection of melamine adulteration in dairy milk by SB-ATR-Fourier transform infrared spectroscopy. Food Chem. 2013;141(3):3066-71.

Jenkins DM, Delwiche MJ. Manometric biosensor for on-line measurement of milk urea. Biosens Bioelectron. 2002;17:557-63.

Jirankalgikar NM, De S. Detection of tallow adulteration in cow ghee by derivative spectrophotometry. J Nat Sci, Biol, Med. 2014:5(2):317-9.

Kaminarides SE, Koukiassa P. Detection of bovine milk in ovine yoghurt by electrophoresis of para-k-casein. Food Chem. 2002;78:53-5.

Kamthania M, Saxena J, Saxena K, Sharma DK. Methods of Detection \&Remedial Measures. Int J Engg Tech Res. 2014;1:15-20.

Kandpal SD, Srivastava AK, Negi KS. Estimation of quality of raw milk (open \& branded) by milk adulteration testing kit. Indian J Comminity Health. 2012;24:3.

Kasemsumran S, Thanapase W, Kiatsoonthon A. Feasibility of near-infrared spectroscopy to detect and to quantify adulterants in cow milk. Analytical Sci. 2007;23(7):907-10.

Kavita P. Studies on the levels of urea in milk. Karnal: NDRI; 2000.

Khan KM, Krishna H, Majumder SK, Gupta PK. Detection of urea adulteration in milk using near-infrared Raman spectroscopy. Food Anal. Methods. 2014

Kim A, Barcelo SJ, Williams RS, Li Z. Melamine sensing in milk products by using surface enhanced Raman scattering. Anal Chem. 2012;84(21):9303-9.

Klotz A, Einspanier R. Development of a DNAbased screening method to detect cow milk in ewe, goat and buffalo milk and dairy products using PCR-LCREIA-technique. Milchwissenschaft. 2001;56:67-70.
Kolar CW, Cho IC, Watrous WL. Vegetable protein application in yogurt, coffee creamers and whip toppings. J Am Oil Chem Soc. 1979;56:389-91.

Kumar R, Singh DK, Chawla NK. Adulteration/contamination of milk demystified. Indian Dairyman. 1998;50:25-33.

Kumar A, Lal D, Seth R, Sharma R. Recent trends in detection of adulteration in milk fat a review. Indian J Dairy Sci. 2002;55:319-30.

Lawley R. Melamine vol. 2016. Food Safety Watch. 2013

Lechner E, Klostermeyer H. NachweisEinerVerfälschung Von MagermilchpulverMitMolkenpulver (PolarographischeMethode). Milchwissenschaft. 1981;36:267-70.

Lin M, He L, Awika J, Yang L, Ledoux DR, Li HA, Mustapha A. Detection of melamine in gluten, chicken feed, and processed foods using surface enhanced Raman spectroscopy and HPLC. J Food Sci. 2008;73(8):T129-34.

Liu B, Lin M, Li H. Potential of SERS for rapid detection of melamine and cyanuric acid extracted from milk. Sensing Instrum Food Qual Saf. 2010;4(1):13-9.

Liu Y, Todd EED, Zhang Q, Shi JR, Liu XJ. Recent developments in the detection of melamine. J Zhejiang Univ Sci B (Biomed \& Biotechnol). 2012;13(7):525-32.

López-Calleja I, González I, Fajardo V, Rodríguez MA, Hernández PE, García T, Matín R. Rapid detection of cows' milk in sheeps' and goats' milk by a species-specific polymerase chain reaction technique. J Dairy Sci. 2004;87:2839-45.

Majcher MA, Kaczmarek A, Klensporf-Pawlik D, Pikul J, Jeleń HH. SPME-MS-based electronic nose as a tool for determination of authenticity of PDO Cheese, Oscypek. Food Anal Methods. 2015;8(9):2211-7.

Manual of Methods of Analysis of Foods: Milk and Milk Products. 2005 D. G. o. H. Services (Ed.)): Ministry of Health and Family Welfare, Government of India

Maraboli A, Cattaneo TMP, Giangiacomo R. Detection of vegetable proteins from soy, pea and wheat isolates in milk powder by near infrared spectroscopy. J Near Infrared Spectros. 2002;10:63-9.

Maudet C, Taberlet P. Detection of cows' milk in goats' cheeses inferred from mitochondrial DNA polymorphism. J Dairy Res. 2001;68:229-35.

May CD, Fomon SJ, Remigio L. Immunological consequences of feeding infants with cow milk and soy products. Acta Paediatr Scand. 1982;71:43-51.

Meisel $\mathrm{H}$. Application of fourth derivative spectroscopy to quantitation of whey protein and casein in total milk protein. Milchwissenschaft. 1995:50:247-51.

Michael Smoker, A. J. K. Interim Method for Determination of Melamine and Cyanuric Acid Residues in Foods using LC-MS/MS: Version 1.0. In: U.S. Food nd Drug Administration. 2008

Mishra GK, Mishra RK, Bhand S. Flow injection analysis biosensor for urea analysis in adulterated milk using enzyme thermistor. Biosensors and Bioelectronics. 2010;26:1560-4.

Moore JC, Spink J, Lipp M. Development and Application of a Database of Food Ingredient Fraud and Economically Motivated Adulteration from 1980 to 2010. J Food Sci. 2012;77:R108-16.

Ntakatsane MP, Liu XM, Zhou P. Short communication: Rapid detection of milk fat adulteration with vegetable oil by fluorescence spectroscopy. J Dairy Sci. 2013;96(4):2130-6.

Okazaki S, Hiramatsu M, Gonmori K, Suzuki O, Tu AT. Rapid nondestructive screening for melamine in dried milk by Raman spectroscopy. Forensic Toxicol. 2009;27:94-7.

Qin J, Chao K, Kim MS. Simultaneous detection of multiple adulterants in dry milk using macro-scale Raman chemical imaging. Food Chem. 2013;138:998-1007.

Recio I, Perez-Rodrlguez ML, Ramos M, Amigo L. Capillary electrophoretic analysis of genetic variants of milk proteins from different species. J Chromatogr A. 1997;768:47-56.

Renny EF, Daniel DK, Krastanov Al, Zachariah CA, Elizabeth R. Enzyme based sensor for detection of urea in milk. Biotechnol Biotechnol Equip. 2005;19(2):198-201.

Renny EF, Daniel DK, Krastanov Al, Zachariah CA, Elizabeth R. Enzyme based sensor for detection of urea in milk. Biotechnol Biotechnol Equip. 2014;19(2):198-201.

Romero C, Perez-Andújar O, Olmedo A, Jiménez S. Detection of cow's milk in ewe's or goat's milk by HPLC. Chromatographia. 1996;42:181-4.

Ruicheng Wei RW, Zeng Q, Chen M, Liu T. High-performance liquid chromatographic method for the determination of cyromazine and melamine residues in milk and pork. J Chromatogr Sci. 2009;47:581-4.

Sanchez L, Perez MD, Puyol P, Calvo M, Brett G. Determination of vegetal proteins in milk powder by enzymelinked immunosorbent assay: Interlaboratory study. J AOAC Int. 2002:85:1390-7.

Sanchez-Monge R, Lopez-Torrejón G, Pascual CY, Varela J, Martin-Esteban M, Salcedo G. Vicilin and convicilin are potential major allergens from pea. Clin Exp Allergy. 2004;34:1747-53. 
Santos PMd, Costa LFB, Pereira-Filho ER. Study of Calcium and Sodium Behavior to Identify Milk Adulteration Using Flame Atomic Absorption Spectrometry Food Nutri Sci. 2012; 1228-1232.

Santos PM, Pereira-Filho ER, Rodriguez-Saona LE. Application of Hand-Held and Portable Infrared Spectrometers in Bovine Milk Analysis. J Agric Food Chem. 2013a;61:1205-11.

Santos PM, Pereira-Filho ER, Rodriguez-Saona LE. Application of hand-held and portable infrared spectrometers in bovine milk analysis. J Agri Food Chem. 2013b;61(6):1205-11.

Satoh R, Nakamura R. Proteomic analysis of known and candidate rice allergens between non-transgenic and transgenic plants. Regul Toxicol Pharmacol. 2011:59:437-44

Saz JM, Marina ML. High performance liquid chromatography and capillary electrophoresis in the analysis of soybean proteins and peptides in foodstuffs. J Sep Sci. 2007;30:431-51.

Scholl PF, Farris SM, Mossoba MM. Rapid turbidimetric detection of milk powder adulteration with plant proteins. J Agric Food Chem. 2014;62:1498-505.

Sharma SK, Hill AR, Mittal GS. An improved method to measure glycomacropeptides (GMP) in renneted milk. Milchwissenschaft. 1993:48:71-3.

Sharma RSR, Barui AK, Ed. Rapid Methods for Detection of Adulterants in Milk Chemical analysis of value added dairy products and their quality assurance. National Dairy Research Institute; 2011.

Sharma R., Rajput Y. S., Barui A. K., \& N., L. N. Detection of adulterants in milk, A laboratory manual. In N. D. R. Institute (Ed.)). Karnal-132001, Haryana, India. 2012.

Sherri Turnipseed, CC Cristina Nochetto, David N. Heller. Determination of melamine and cyanuric acid residues in infant formula using LCMS/MS. In: U.S. Food nd Drug Administration. 2008

Siciliano RA, Rega B, Amoresano A, Pucci P. Modern mass spectrometric methodologies in monitoring milk quality. Analytical Chem. 2000;72:408-15.

Singh P, Gandhi N. Milk preservatives and adulterants: processing, regulatory and safety issues. Food Rev Int. 2015;31(3):236-61.

Singhal OP. Adulterants and methods for detection. Indian Dairyman. 1980;32(10):771-4.

Singuluri $\mathrm{H}$, Sukumaran M. Milk adulteration in hyderabad, India - a comparative study on the levels of different adulterants present in milk. J Chromatograph Separat Techniq. 2014;5:212.

Song $H$, Xue $H$, Han Y. Detection of cow's milk in Shaanxi goat's milk with an ELISA assay. Food Control. 2011;22(6):883-7.

Souza SS, Cruz AG, Walter EHM, Faria JAF, Celeghini RMS, Ferreira MMC, Granato D, Sant'Ana ADS. Monitoring the authenticity of brazilian uht milk: a chemometric Approach. Food Chem. 2011;124:692-5.

Strange ED, Malin EL, Van Hekken DL, Basch JJ. Chromatographic and electrophoretic methods used for analysis of milk proteins. J Chromatogr A. 1992;624:81-102.

Tamime AY, Barclay MNI, Law AJR, Leaver J, Anifantakis EM, O'connor TPO. Kishk - a dried fermented milk/cereal mixture. 2. Assessment of a variety of protein analytical techniques for determining adulteration and proteolysis. Lait. 1999;79:331-9.

Trivedi UB, Lakshminarayana D, Kothari IL, Patel NG, Kapse HN, Makhija KK, Patel $\mathrm{PB}$, Panchal CJ. Potentiometric biosensor for urea determination in milk. Sensors and Actuators B: Chemical. 2009;140:260-6.

Tsai T-H, Thiagarajan S, Chen S-M. Detection of melamine in milk powder and human urine. J Agric Food Chem. 2010;58:4537-44.

Uysal R, Boyaci I, Genis H, Tamer U. Determination of butter adulteration with margarine using Raman spectroscopy. Food Chem. 2013;141(4):4397-403.

Venkatasami G, Sowa JR. A rapid, acetonitrile-free, HPLC method for determination of melamine in infant formula. Analytica Chimica Acta. 2010; 665:227-30.

Veyrand B, Durand S, Machand P, Antignac J-P, Bizec BL, Hancock P. Analysis of melamine and its degrdation Products in milk based products using GC-MS/ MS. Manchester: Waters Corporation; 2009.

Virginia de Lourdes MF, Gouvea MM, de Carvalho Marues FF, Annibal Duarte Pereira N. Is it possible to screen for milk or whey protein adulteration with melamine, urea and ammonium sulphate combinng Kjeldahl and classical spectrophotometric methods? Food Chem. 2013;141:3649-55.

Xin $\mathrm{H}$, Stone R. Tainted milk scandal. Chinese probe unmasks high-tech adulteration with melamine. Science. 2008;322:1310-1.

Xinhua Dai XF, Fuhai S, Yang M, Li H, Zhou J, Xu R. Accurate analysis of urea in milk and milk powder by isotope dilution gas chromatography-mass spectrometry. J Chromatogr B. 2010;878:1634-8.
Yang S, Ding J, Zheng J, Hu B, Li J, Chen H, et al. Detection of melamine in milk products by surface desorption atmospheric pressure chemical ionization mass spectrometry. Analytical Chemistry. 2009;81:2426-36.

Zhang XF, Zou MQ, Qi XH, Liu F, Zhu XH, Zhao BH. Detection of melamine in liquid milk using surface-enhanced Raman scattering spectroscopy. J Raman Spectroscopy. 2010;41(12):1655-60.

Zhu L, Gamez G, Chen H, Chingin K, Zenob R. Rapid Detection of melamine in untreated milk and wheat gluten by ultrasound assisted extractive electrospray ionization mass spectrometry (EESI-MS). Chem Comm. 2009;5:559-61.

\section{Submit your manuscript to a SpringerOpen ${ }^{\circ}$ journal and benefit from:}

- Convenient online submission

- Rigorous peer review

- Immediate publication on acceptance

- Open access: articles freely available online

- High visibility within the field

- Retaining the copyright to your article

Submit your next manuscript at $>$ springeropen.com 